\title{
The Pedagogical Activity in the Training of Teachers: Contributions from the Cultural-Historical Theory
}

\author{
Maria Eliza Mattosinho Bernardes*, Adriano Agricio Alves \\ College of Arts, Sciences and Humanities (EACH), University of São Paulo, São Paulo, Brazil \\ Email: ${ }^{*}$ memberna@usp.br
}

Received 1 May 2015; accepted 4 August 2015; published 7 August 2015

Copyright (C) 2015 by authors and Scientific Research Publishing Inc.

This work is licensed under the Creative Commons Attribution International License (CC BY). http://creativecommons.org/licenses/by/4.0/

(c) (;) Open Access

\begin{abstract}
This research analyzes the personal transformation process of students in the teacher training course, from the mediation of theoretical knowledge on the relationship among teaching, learning, and human development. The goal is to investigate the influence of the set of action methods in the pedagogical activity, in the training of future natural science teachers. The issue is analyzed from the Cultural-Historical Theory, from which three aspects are highlighted: the constitution and the development of human psyche through symbolic mediation in social relationships: learning as the trigger for the development of higher psychological functions; and the importance of scientific concepts in the development of higher psychological functions in subjects. Data were collected through a field research that used questionnaires sent to students in the teacher training course of a large state university in Brazil, in classes of 2013 and 2014, and another questionnaire to the monitors of the respective groups. The analysis of data is based on the relationship between the frequency of answers and the subjects' narrative from the analysis elements: reasons and life experiences, teaching processes, contents, learning evaluation, and personal transformation. The results show the influence of the action methods in the pedagogical activity, which aims to the personal training of students and the relevance of collective and collaborative actions in the active participation of all subjects in the teaching and learning process.
\end{abstract}

\section{Keywords}

Teacher Training, Pedagogical Activity, Cultural-Historical Theory, Teaching and Learning, Psychological Development

\footnotetext{
${ }^{*}$ Corresponding author.
} 


\section{Introduction}

The study on teacher training, from the mediation of psychological theories on learning and human development, is aimed at investigating the thing which pedagogical activity (Bernardes, 2012) aspects may create the necessary conditions to promote changes in the consciousness of subjects under study activities (Leontiev, 1983), in professional training. The general problematics of this research is based on the following questions:

1) Which life experiences in the teacher training activity, at undergraduate level, which favors the formation of critical consciousness in regards to their social function, in the formal education area?

2) What is the importance of teaching contents and actions in the process of internalization of concepts and in the personal transformation of future teachers?

3) Which elements in learning evaluation show the achievement of theoretical knowledge by the future teachers and its use in social practices?

Such questions guide the field investigation on the teacher training, which is based on the cultural-historical psychology (Vygotsky, 1996) and on the historical-critical pedagogy (Saviani, 2003).

\subsection{Cultural-Historical Aspects in the Psychological Constitution and Development of Subjects}

The constitution of a subject is understood, in cultural-historical psychology, as a historical, active, and social process. The relationships among subjects and the concrete society, with its multiple determining factors, are dialectically intended in the transformation of both the subjects and society itself, from consciously-organized actions. Under certain conditions, subjects are considered to achieve the social development that is characteristic of the human species, through the mediation of signs and instruments, through the internalization of symbolic systems (Vygotsky, 1996; Luria, 1987; Leontiev, 1983). Thus, the biological base and the mediating conditions in society integrate the unit that comprises elementary and higher functions of subjects under development. According to Oliveira (2010: p. 23), in the historical process of psychological development, subjects need "[...] to acquire a minimum level of the cultural heritage that was historically and socially created by several generations in order to materialize oneself as a social being”.

Thus, the symbolic mediations are understood to be considered the determining factor for the constitution and development of higher psychological functions in subjects. In cultural-historical psychology, the idea of spontaneous and maturational development is overcome by the conception that is mediated by the constitution of the psyche as an essential character for the education of subjects in an activity. Therefore, subjects, for being in mediated activity, are considered to assume the configuration of social beings, and the psychological development of subjects in an activity is potentialized through the appropriation of the historically-created culture (Leontiev, 1983; Davidov, 1988).

\subsection{Education as a Mediating Activity in the Psychological Development Process}

From such conception of the human objectification and subjectification processes in singular subjects, education is generally understood as a mediating activity that is based on social and personal transformation process. However, as stated by Vygotsky (2010), the proper organization of the educational activity is considered to potentialize the process of human psychological development.

In that sense, the importance of school education and pedagogical activity stands out, and it is understood as a dialectical unit between the learning and the study activities (Bernardes, 2009, 2012). They are considered essential in order to potentialize the development of subjects. In contemporary society, school education takes over the task to create ways for the knowledge that was historically produced by mankind to be mediated and internalized by subjects in an activity and to develop mental abilities that are exclusive to the human race, as stated by Vygotsky $(2007,2010)$. Education is characterized by the author as a set of actions which, when organized in a proper way, provoke qualitative changes in the human psyche constitution, from the mediation of cultural instruments and signs; in the qualitative transformation process of higher psychological functions, the internalization of scientific concepts that were created by the various sciences stand out (Vygotsky, 2010; Kostiuk, 2005), at the moment spontaneous concepts are overcome. Those spontaneous concepts are mediated in the social relationships that are established in the daily life of society.

In the particular field of school education, the studies from several researchers (Leontiev, 1983; Bernardes \& 
Moura 2009; Bernardes, 2009, 2012, 2014; Moura et al., 2010) have been identifying the pedagogical activity (Bernardes, 2009), to be part of the particular activities of teachers and students as learning and study activities, respectively. In the pedagogical activity unit, the reasons, goals, actions, and operations must intend the same goal - the appropriation of concepts and the pedagogical development of subjects in an activity.

In this aspect, the substantial elements in the integrated system of actions and operations in the pedagogical activity are considered to be (Bernardes, 2012, 2014): a) the relationships with the object under study; b) the collective and collaborative actions; c) the theoretical knowledge in the training of teachers. Figure 1 illustrates such system:

In regards to the object under study, the need to consider the historical importance of the concept itself and the system of theoretical relationships with which it is integrated are highlighted, inserting the contents themselves in a logical-historical dimension. In regards to the collective and cooperative actions, emphasis is given the dialog-oriented movement of the concept from the mediation of the social meaning of the object under study, and it aims to overcome the personal sense that is stated in the particular participation from students; emphasis is also given to the control of learning as the objectification of the division of functions among subjects in study and learning activities; and emphasis is also given to the volitional dimension, which covers affective and playful aspects, which aims the respect and valuation of the actions that are executed by all subjects in an activity. In regards to the theoretical knowledge in teacher training, emphasis is given to the relationship among singular, particular, and universal dimensions on the constitution of subjects, as the one which covers what belongs to the human race and what must be objectified in singular subjects, from the particular mediations of human production.

Therefore, the role of the schools is highlighted in the development of students' psyche, as it is understood as a social and political institution that, from managers and teachers, it must plan, organize, and systematize the mediation of historically-created knowledge, in order to develop and potentialize the psychological development of students, and to provide the necessary means to the conscious learning of culture.

To do so, teachers need to resort to pedagogical procedures, for students to be able to appropriate concepts. Therefore, investigating the pedagogical activity, in order to determine which actions and operations effectively promote learning becomes a need when the pedagogical development and the emancipation of subjects is investigated from the mediation of knowledge.

Hence, the pedagogical activity as the instrument that forms human psyche, must be considered as the object of study of pedagogy, because, as Libâneo (2012: p. 38) states, "the education (or, in plural, the educational practices), as a social practice that operates in the training and in the development of human beings, in concrete material and social conditions.

The actions and operations in the pedagogical activity must create the proper conditions among study object and subjects, so the internalization and the appropriation of concepts which transform the intrapsychological dimension can take place-because, as stated by Vygotsky (2007: p. 103), "once internalized, those processes become part of children's independent development acquisitions.

Therefore, "teaching operates a cultural mediation whose role is precisely to promote mental development through learning, converting learning into cognitive, affective, and moral development (Libâneo, 2012: p. 41). Thus, Freitas (2012: p. 130) considers that "learning, as a social process that enables an individual to enter the intellectual lives of other people, lies in the base of human development”, and thus, it transforms its own intellectual potential.

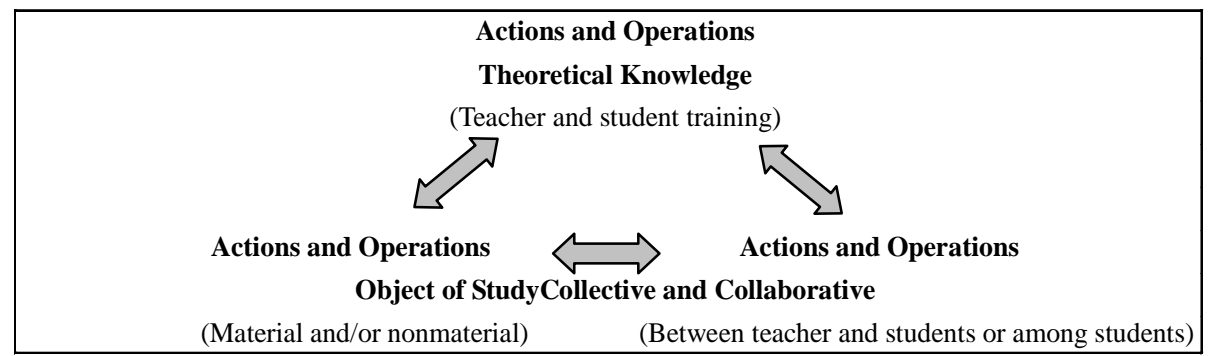

(Bernardes, 2012, p. 208)

Figure 1. Integrated system of actions and operations in the pedagogical activity. 
Thus, the teaching of scientific contents must be considered paramount in educational practices, and it also must orient study activities and be part of students' daily lives. That way, what is expected is that, in school, “[...] learning constitutes a way for developing scientific concepts, as it is the definitive and determining moment of all destinations in the intellectual development of a child” (Facci, 2010: p. 135). Hence, it considers that a school which moves away from those principles does not meet its social function; that is, it is assumed as an institution that does not favor human emancipation.

In that sense, our research aims to investigate the pedagogical activity aspects which create the conditions to promote transformations in the personal dimension of subjects in study activities. Therefore, an effort is made to investigate to which extent the pedagogical procedures in education psychology became operations in the daily lives of students in a teacher training course, and to which extent those procedures promote personal transformations in those students.

\subsection{The Research on the Pedagogical Activity in the Training of Teachers}

The research was conducted in the School of Arts, Sciences, and Humanities of Universidade de São Paulo (Brazil), and it lasted for two years (2013 and 2014). In the technical and methodological fields, the research assumes characteristics of a participatory research (Gil, 1999), and it has the participation of 31 students in four groups of the Natural Science Licentiate course (NSL) that are enrolled in the Education Psychology-from those students, 16 took part in 2013 and 15 in 2014, and they were more the morning and night courses. 4 monitors (master's and doctorate students) who were part of Programa de Aperfeiçoamento de Ensino - PAE (Learning Improvement Program) ${ }^{1}$ —of the university's graduation programs and the teacher-researcher who is responsible for the discipline in the Natural Science Licentiate course also took part of the study.

Learning in the Education Psychology discipline is organized from three axes: a) the world and Brazilian history of psychology in education (Tanamachi \& Meira, 2003; Guzzo, 2010); b) theories on development and learning (Piaget, 1983; Vygotsky, 1996); c) school failure (Patto, 1983; Asbahr \& Lopes, 2006); d) Theoretical and practical analysis of life experiences in the regular school.

The learning actions and operations are shared between the teacher who is responsible for the discipline and the group monitors in the learning of teachership, from the collective work proposal which presupposes a set of action methods in the pedagogical activity (Bernardes, 2012); they are directly related to study actions and operations to be performed by the students. Table 1 indicates the actions and operations that are integrated to the actions methods in the pedagogical activity: teacher, monitor, and students.

From the set of described action methods in the pedagogical activity, the evaluation of learning and teaching is conducted through the analysis of the following elements: a) weekly production of students on read texts-the individual answer to a questions that guides the study of a theoretical text; b) individual portfolio which contains:

\section{Table 1. Action methods in the pedagogical activity in teacher training.}

Subjects in
an activity \begin{tabular}{l} 
Actions and operations \\
*Teacher $\begin{array}{l}\text { a) Organize the teaching and the collective work meetings; b) Supervise the action of monitors in the learning } \\
\text { of teachership; c) Give dialogged lectures; d) Prepare the textbooks; e) Guide students' study actions; f) Propose } \\
\text { theoretical problems in accounts of life experiences of students at school; g) Individually or collectively clarify } \\
\text { conceptual and/or practical doubts of students; h) Analyze students' final papers, as the expression of their } \\
\text { theoretical and practical learning. } \\
\text { *Monitors } \\
\text { a) Take part in collective work meetings with the teacher in charge; b) Follow up and guide study actions from } \\
\text { students; c) Read and comment students' learning records (weekly summaries of texts and portfolios to be studied); } \\
\text { d) Take an active part in dialogged lectures; Give a dialogged lecture as a learning exercise in higher-education } \\
\text { teachership; f) Individually or collectively clarify conceptual and/or practical doubts from students. } \\
\text { a) Study the contents of the program through the previous reading of texts that are indicated in the discipline corpus; } \\
\text { b) Prepare weekly summaries of read texts individually (1 page) -answer to a study-orienting question; c) Take an } \\
\text { active part in the theoretical reflections in the dialogged lecture; d) Take part in collective study and reflection actions } \\
\text { (small groups) on the theoretical contents; e) Present a portfolio, at the end of each study axis, as a record for the } \\
\text { learning and teaching process; f) Prepare (in duos) the final discipline paper, that is the record of the theoretical } \\
\text { and practical analysis of school reality (the context in which they will be inserted as future teachers). }\end{array}$ \\
\hline
\end{tabular}

${ }^{1} \mathrm{PAE}$ is mainly intended to improve the training of holders of graduate degrees for the didactic activity of graduation, and it is composed of two stages: Pedagogical Preparation and Supervised Teaching Internship. 
the weekly study record that is commented by the monitors, the record of theoretical reflections that are conducted during classes; a summary of the conceptual learning; c) the final discipline paper, which analyzes the relationship between teaching and learning in regular schools, in the knowledge area in which the student intends to act as a teacher; d) an analysis of actions in the organization of teaching that are conducted by the teacher and the monitors.

\section{Methodological Procedures}

The analysis of field research data is conducted in a qualitative approach (Richardson, 1999), and it makes use of the questionnaire that was sent to all students, and of another questionnaire that was sent to discipline monitors in investigated groups.

The questionnaire that was sent by e-mail to the students was available between August 04 and September 01, 2013; and from August 25 to September 01, 2014.

The questionnaire comprised 13 open and closed questions which aimed to investigate: a) the opinion of students on the pedagogical actions that are used in the Education Psychology classes; b) the difficulties that are faced by the students; c) the impact the discipline contents promoted in the transformation of their consciences; d) the way by which students understand the concrete reality. A questionnaire with 7 open questions was sent to monitors in the periods between September 4 to 6, 2013; and from August 25 to September 01, 2014. That instrument intended to get the monitors' opinions on: a) the impact of pedagogical actions on the development of students; b) the learning manifestations of students through the pedagogical activity under analysis.

From the answers that were obtained in the questionnaires from students and monitors, the following analysis elements were identified: a) reasons and life experiences; b) teaching processes; c) taught contents; c) learning evaluation; and d) personal transformation.

The data that were obtained through the questionnaires on life experiences refer to previous contacts with knowledge regarding psychology by students. In the case of the reasons, the reasons why students attend the Education Psychology discipline are analyzed. In regards to teaching processes, the effectiveness of the action methods in the pedagogical activity is investigated. The taught contents and the processes of learning and teaching evaluation are analyzed as fundamental elements, as they are considered to be mediators in the process of personal transformation of students in their professional training. Such analysis elements were also covered in the questionnaire for monitors.

\section{Results and Analyses}

The results presented next show the answers from the students and from the monitors, which are connected to one another and to analysis elements that cover the frequency and the narrative of research participants, from questions that were inserted in the questionnaires. The analysis of the data and the presentation of results is based on the grouping of answers from students and through their similarities; for that reason, not all answers are presented in this study.

\subsection{Life Experiences and Reasons}

The life experiences of each subject are understood to be fundamental in the formation of their personality, as they mediate social meanings which impact the way of thinking and acting of subjects in different activities. Concerning that, the reasons are considered as elements which drive and lead subjects to choose and take certain measures rather than others, and to appropriate the objects which satisfy their needs. According to Leontiev (1983), the reasons do not exist for themselves, they relate to the needs and they are constituted as guidance for the actions of subjects in any activity.

In the case of the reasons that are analyzed in this research, only the reasons why the students attend the discipline under analysis are investigated. Thus, the investigations conducted in this block will give us a specific and partial understanding of the complexity of the reasons why students are in that activity. We asked students why they enrolled in the discipline during the related semester. That question was followed by some choice options, which were: a) following the sequence of the course program; b) choosing to study the theoretical subjects first; c) indication from more experienced students; d) I liked the themes which would be included; and d) others. 
In 2013's groups, $81 \%$ of the students (13 students) claimed that their reason to attend the discipline is related to following the course program, whereas $19 \%$ of them (3 students) claimed they liked the themes that would be discussed in the classes. In turn, for 2014's groups, we had a percentage of $73 \%$ (11 students) stating that the reason was related to the compliance with the course program, $7 \%$ decided to take theoretical disciplines first, and $20 \%$ stated 'others', but they did not describe which were the reasons.

Most students are verified not to have reasons that relate to the need to appropriate the contents of the discipline in their professional training, but they mention the compliance with the course program. That reason is not considered sufficient for students to start the study activity. Such fact requires the teacher to articulate actions in the pedagogical activity which elicits effective reasons (Leontiev, 1983) for students to integrate to the pedagogical activity. As stated by Moura et al. (2010: p. 90), the teacher's teaching activity is what should generate and promote the activity from students. It should give the students a special reason for their activities: theoretically studying and learning about reality. That occurs because students, upon getting in touch with the discipline contents, may develop new reasons to transform the way through which they understand and act on reality. The new reasons are formed from the action methods of the teacher and from the meaning the studied contents have for students.

In regards to past life experiences in the Education Psychology area, the data indicate that: in 2013, 19\% of students (13) answered that they already had experiences in the Education Psychology area; in turn, 81\% (13 students) answered that they had never had any experiences in the teaching area. In the class of 2014, the answers had more balanced data. Of all respondents, 60\% (9 students) had never had any experiences with the discipline, whereas $40 \%$ of them point out that they already knew related areas.

Most students which attended the discipline in 2013 and 2014 are noticed not to have had previous experiences in that area, and the reason to attend it is institutional in character. That way, it is possible to identify some characteristics from students before they enrolled in that discipline.

\subsection{Teaching Processes and Studied Contents}

According to the Cultural-Historical Theory of the human psyche, the subjects in an activity appropriate culture through their life experiences, the same way through which the higher mental processes are developed. Thus, being active is considered a determining factor for the development of higher psychological functions. To Leontiev et al. (2005), it is in the active process that the subjects' actions turn into operations. However, for a subject to "appropriate the objects or phenomena, it is necessary to undertake an activity that is proper to the contents in the object or phenomenon that is given.” (p. 94).

The chart below shows some of the answers that represent the way of thinking of the set of students, when they analyze of the aspects of the action methods in the pedagogical activity, in Table 2.

The answers from the students show the following aspects: a) valuation of the theoretical knowledge and of the explanatory intervention of the discipline teacher; b) connection between the knowledge and the daily life; c) the need for higher interactivity among subjects.

\section{Table 2. Student conceptions on dialogged lectures.}

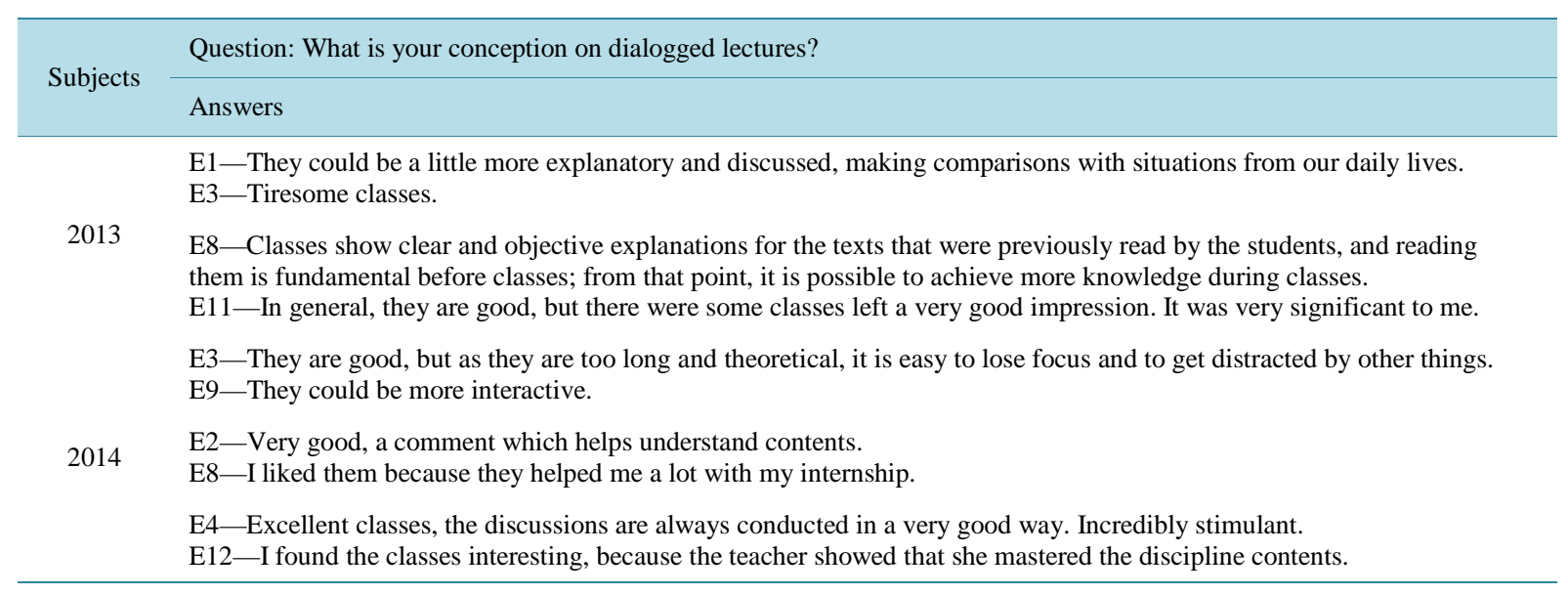


In regards to theoretical knowledge, students are verified to execute study actions before classes, and they can have more active participation in the dialogic process of the concept in the classroom. That is the interpsychological dimension, which is objectified in the intrapsychological one (Vygotsky, 1996). However, in the movement to internalize each concept, each subject presents the summary of their life experiences and of their previously-appropriated knowledge (Bernardes, 2014). In the dialogic process of concepts, each student who executes study actions and tasks is verified to have a more active participation in the pedagogical activity. In those cases, the initial reasons, which relate to the execution of study tasks, are more and more transformed in new reasons for conscious learning. In those cases, it is possible to integrate the theoretical concepts to daily life concepts. Some students are verified to value the theoretical-practical relationship, but others cannot. That is the subjective dimension which is not objectified in the daily life. The need to review interaction actions among students is also identified in the organization of teaching, so they can participate more in the dialogic process. However, it is not possible to ensure, through such actions, that the process is objectified among all students, in case there is not previous study of the contents in a class program.

The previous study of the contents through the corpus is part of the investigation process, and the results show the difficulty students face when they try to understand the theoretical contents without the teacher's explanatory intervention, and they also show the difficulties from the students to execute that study task. In the chart below are the percentage values of answers, in Table 3.

The difficulty to understand the theoretical concepts without the pedagogical intervention is made clear, and the most probable hypotheses for such fact relate to the complexity of studied concepts, or even to the social conditions that made reading and study activities difficult.

However, the individual production of a text in response to a study-guiding question, one of the actions students had to execute in the action methods in the pedagogical activity, creates a need for study and learning control. Such task needs to be done by students in an activity, even if there is partial understanding in the internalization of theoretical concepts. Such texts were analyzed, commented on, and developed in an individual way by group monitors (in the week after the class) to students, with recommendations for improvements in text production.

Next, the comments from the monitors are shown in regards to the evolution of students upon executing that study task, in Table 4.

The active participation from the monitors in the supervision of the study process of theoretical concepts is considered to be fundamental for conscious learning to exist in the pedagogical activity of teacher training. Individualized supervision, which is oriented towards the solving of individual difficulties of students, is considered the didactic element that integrates learning and study actions in the pedagogical activity. When the supervision of study is not conducted in an effective way or when it is fragile in regards to conceptual and affective areas, learning quality is perceived to be reduced, or it is not objectified in a way to meet the teaching goals in the pedagogical activity.

Another set of actions and operations in the pedagogical activity to be analyzed are the life experiences by students at schools ( $30 \mathrm{~h}$ total: $10 \mathrm{~h}$ of practice; $10 \mathrm{~h}$ of study; $10 \mathrm{~h}$ of report production) with the purpose to analyze the teaching and learning processes, and the psychological development of children and youngsters in basic education. Such life experiences aim at the theoretical and practical understanding of studied concepts in

Table 3. Life experiences in regards to the reading of texts studied in the classes.

\begin{tabular}{|c|c|c|}
\hline \multirow{2}{*}{ Life experiences_-reading of the texts } & \multicolumn{2}{|c|}{ Answers } \\
\hline & Class of $2013(\%)$ & Class of $2014(\%)$ \\
\hline Could understand the texts after class & 37 & 47 \\
\hline Had difficulty understanding the texts & 34 & 7 \\
\hline Had no difficulty understanding the texts & 12 & 7 \\
\hline Did not read the texts before class & 3 & 0 \\
\hline Had a job, and had not time to read the texts & 14 & 13 \\
\hline Others & 0 & 26 \\
\hline
\end{tabular}


the education psychology discipline, in the knowledge area in which students intend to operate as future teachers. That action is not directly supervised in schools; the proposal of theoretical and practical problems from student accounts take place more generally in education psychology classes, by teachers/researchers and by monitors. Such reflections aim to transform the theoretical contents that are studied in the discipline in mediators for the understanding and explanation of school reality.

In regards to the life experiences in basic education schools, it is important to indicate that, in the class of 2013, 50\% of students could establish a relationship between the studied theory and the pedagogical practice at schools; the students who faced difficulties, in turn (half of the respondents) reports that the educational reality is much different from what is described in the theories; others say that they would need to further study the discipline so they could better observe the teaching relationships at schools.

In the class of $2014,70 \%$ of students said it was possible to identify theoretical and practical relationships at schools. The remaining 30\% said they could not see the practical relationship between studied contents in the discipline with basic education; they claim that further studying on the contents would be needed, as well as more time for observations, in Table 5.

The data presented are analyzed in two aspects: a) the relationship between the pedagogical practice and the theoretical contents; b) the conditions in which the life experiences were conducted at schools.

One may state that the theoretical and practical unit in the training of future teachers is objectified among those who appropriate studied contents in the discipline, and some students state that they found it difficult to analyze the pedagogical practices as they did not have enough theoretical knowledge; other students can, with a certain ability, analyze reality from the knowledge that was appropriated in their training.

Table 4. Opinion from the monitors on the texts from the students.

Monitors $\begin{aligned} & \text { Question: Was there improvement in the texts written by the students and corrected by you? } \\ & \text { Answers } \\ & \text { M. } 1\end{aligned} \begin{aligned} & \text { It was a very important differential for the learning of students, as they needed to read the texts before the classes. That } \\ & \text { method also helped improve the writing skill and the power of synthesis from students. We observed the evolution of the } \\ & \text { understanding of studied themes, and also the critical writing factor for students along the process. }\end{aligned}$
$\begin{aligned} & \text { There was definite improvement. And that improvement is exclusively due to the gradual comprehension of the experienced } \\ & \text { process: in regards to the proposed objectives, to the teacher's committed stance, to the choice of the materials, to the } \\ & \text { didactic choice (previous reading and summary, class, correction, and returning of texts), and to the required engagement } \\ & \text { by students. }\end{aligned}$
$\begin{aligned} & \text { I noticed a clear improvement in the work from students. Initially, they could not even correctly mention the authors of texts } \\ & \text { used; they ended up plagiarizing without knowing they were doing it. As the time went by, they started citing the authors, } \\ & \text { and there was also improvement in the presentation of texts, and in the clarity of ideas. Many of them improved their work } \\ & \text { a lot. } 3\end{aligned}$
$\begin{aligned} & \text { The process of a higher investment and care in the process of written production is visible. Besides that, corrections } \\ & \text { were mostly incorporated by students, which helped them build better quality summaries. }\end{aligned}$

Table 5. Life experiences in basic education and the relationship with studied contents.

\begin{tabular}{|c|c|}
\hline \multirow{2}{*}{ Subjects } & Question: Was there a relationship between the theoretical contents and the practices that are experienced at schools? \\
\hline & Answers \\
\hline 2013 & $\begin{array}{l}\text { E8-Yes, the subjects that were exposed in classroom were put to practice in the observation at school. } \\
\text { E12-Yes, the examples focused on concrete situations. } \\
\text { E3 - It was very hard, as the practices at school are far from being the "ideal type" that was proposed by studied authors. } \\
\text { E15-Vaguely, due to my scarce theoretical knowledge. }\end{array}$ \\
\hline 2014 & $\begin{array}{l}\text { E3-Further theoretical studies or more observation time would be required. } \\
\text { E11-Yes. Completely. The things that were learned in class (the development theories, the way to understand the } \\
\text { umanization process, etc.) changed my way to comprehend the concrete reality, and more specifically, the importance } \\
\text { of learning for student development. I went to school and I could relate what I saw to what I had theoretically learned. } \\
\text { I experienced, for example, that the methods of teachers is permeated and guided by the way through which he } \\
\text { understands learning and development. }\end{array}$ \\
\hline
\end{tabular}


One of the aspects to be analyzed are the concrete conditions for students to perform their life experiences at their schools, with the purpose to analyze the pedagogical practices. One may state that those life experiences could acquire a new meaning for the students in case they are followed by a teacher who proposes different approaches for the pedagogical practices, and who contextualized the contents presenting problems for students to solve, explain, and present possibilities for those to be overcome in the observed reality. However, such life experiences are not considered as supervised internship in the program of undergraduate courses ${ }^{2}$; they are considered as the practical part of a theoretical and practical discipline in the training of future teachers, a fact which makes interventions from teachers impossible in the training activity.

\subsection{Learning Evaluation}

The evaluation of the teaching and learning process is conceived in a way that should not be understood in a fragmented fashion, as it is part of the action methods in the pedagogical activity that aims to appropriate knowledge and to psychologically develop all subjects who integrate it. In that sense, both learning and teaching need to be submitted to critic analysis, both by students and teachers, who are responsible for learning organization. In that sense, considering that "act of evaluating does not stand on itself, but it exists to serve the project it is connected to. Its definitions and instruments need to be configured in compliance with the outline of the project it serves” (Luckesi, 2012: p. 448).

In the Education Psychology discipline, the following instruments were used to evaluate the learning of students: a) individual text—summary of the study from a guiding question; b) portfolios for each study content; c) final paper-theoretical and practical analysis of life experiences at school. The use of several evaluation instruments is aimed at capturing the process for the transformation of reasoning and of language for the students in the activity. In this aspect, we are interested in analyzing the movement of concept internalization and the appropriation of them in the critical analysis of school reality.

Such instruments were submitted to the analysis from students to verify their effectiveness in evaluating teaching. When they were asked what the most proper evaluation instruments to capture the students' learning transformation and psychological development processes were, most students (2013 and 2014) identify the portfolio as the most adequate instrument, as they evaluate learning as a process. Besides that aspect, students identify that, in the portfolio construction, it is possible to experience self-evaluation, as they can analyze and review their own study processes, and the processes used to learn theoretical concepts. Table 6 shows some students' contributions.

\section{Table 6. Table type styles (table caption is indispensable).}

\begin{tabular}{|c|c|}
\hline \multirow{2}{*}{ Year } & Question: What is the evaluation instrument that you see as the most proper to analyze learning? \\
\hline & Answers \\
\hline \multirow{3}{*}{2013} & $\begin{array}{l}\text { E3-The portfolios, as they demand continuous work to be concluded. That way the relationship with the contents is one } \\
\text { of work and re-reading, and not one that simply regards to exposure. }\end{array}$ \\
\hline & $\begin{array}{l}\text { E5-The portfolio, as it shows knowledge under evolution, where there are changing opinions and changing understanding } \\
\text { of concepts from a portfolio to another. }\end{array}$ \\
\hline & E12-The portfolios, as, in order to do them, I would have to read the texts and then further read about the subject. \\
\hline \multirow{4}{*}{2014} & $\begin{array}{l}\text { E4-The portfolio, as it considers a "more complete" activity. It allows, for example, a deeper comparison between } \\
\text { lectures (through notes taken at classes) with the texts that are used in the classes. }\end{array}$ \\
\hline & E8-The portfolio. Because it allowed me to follow my learning during the class period. \\
\hline & $\begin{array}{l}\text { E11-I believe the portfolio contributes to my learning process when it put me through constant study activities. In other } \\
\text { words, as the portfolio comprises activities that are performed throughout classes, I needed to do them throughout the } \\
\text { discipline with dedication, commitment, and perseverance. In that sense, I learned many things throughout the classes, } \\
\text { which contributed to my development. }\end{array}$ \\
\hline & $\begin{array}{l}\text { E15-The portfolio. Because it is gradually built, unlike tests, which are taken at a single time, which may generate } \\
\text { anxiety, making the construction of thinking difficult. }\end{array}$ \\
\hline
\end{tabular}

${ }^{2}$ The supervised internship in the related undergraduate course has the supervision of an education professional in partner schools for students to undergo the required internship hours in their professional training. The role of that educator is to supervise and get students to fully enjoy their internship, proposing collaborative activities in basic education schools. 
The research data show that the portfolio is an effective pedagogical instrument to be used by teachers when they wish to identify the learning process of students, reorganize teaching actions when the learning records do not correspond to the goals of the teaching and learning process. For students, the portfolio helps them identify their difficulties, and it records their learning, making it active and responsible in the appropriation of knowledge.

With the obtained results, the importance of the portfolio as an evaluation tool became evident. In the class of 2013, only three students chose tests as the best evaluation instruments, but they did not explain why. In the class of 2014, only one student wrote: "I prefer assignments, mainly the ones in loco, as I experience practical learning", whereas all remaining students chose the portfolios. That way, the evaluation potential is made evident in the set of action methods in the pedagogical activity.

\subsection{Personal Transformation}

The personal transformation process is conceived as the development of higher psychological functions, and it takes place through life experiences, when the meanings are mediated and appropriated by the subjects in an activity. Thus, throughout their development, subjects internalize culture elements through interpsychological relationships, which are objectified in intrapsychological relationships; that is, the individual is humanized in the relationship between themself and society. Thus, the teaching processes are deemed indispensable for a subject's development. In the analyzed pedagogical practice herein, the aim is to potentialize the development of students through the mediation of pedagogical theories on learning, development, and the appropriation of theoretical concepts by them.

The influence of teaching is verified in the obtained data in the way students start understanding the concrete reality. Thus, the learning of theoretical concepts creates new possibilities, as stated by Luria (2005), for men to actively relate to the world which gave rise to him, qualitatively transforming his psyche.

In Table 7 are some answers from students on the impact the discipline caused in their personal and professional training, as well as in the way it comprehends the concrete reality.

The positive impact the discipline caused in the training of students is evident, whether as future teachers or in the relationships with daily life. The changes that were mentioned by the students make the importance of action methods evident in the pedagogical activity in the Education Psychology discipline, as the theoretical mediations are noticed to transcend the study context, causing impact to students' lives. Therefore, despite the difficulties

Table 7. Influence of learning in the personal and professional training.

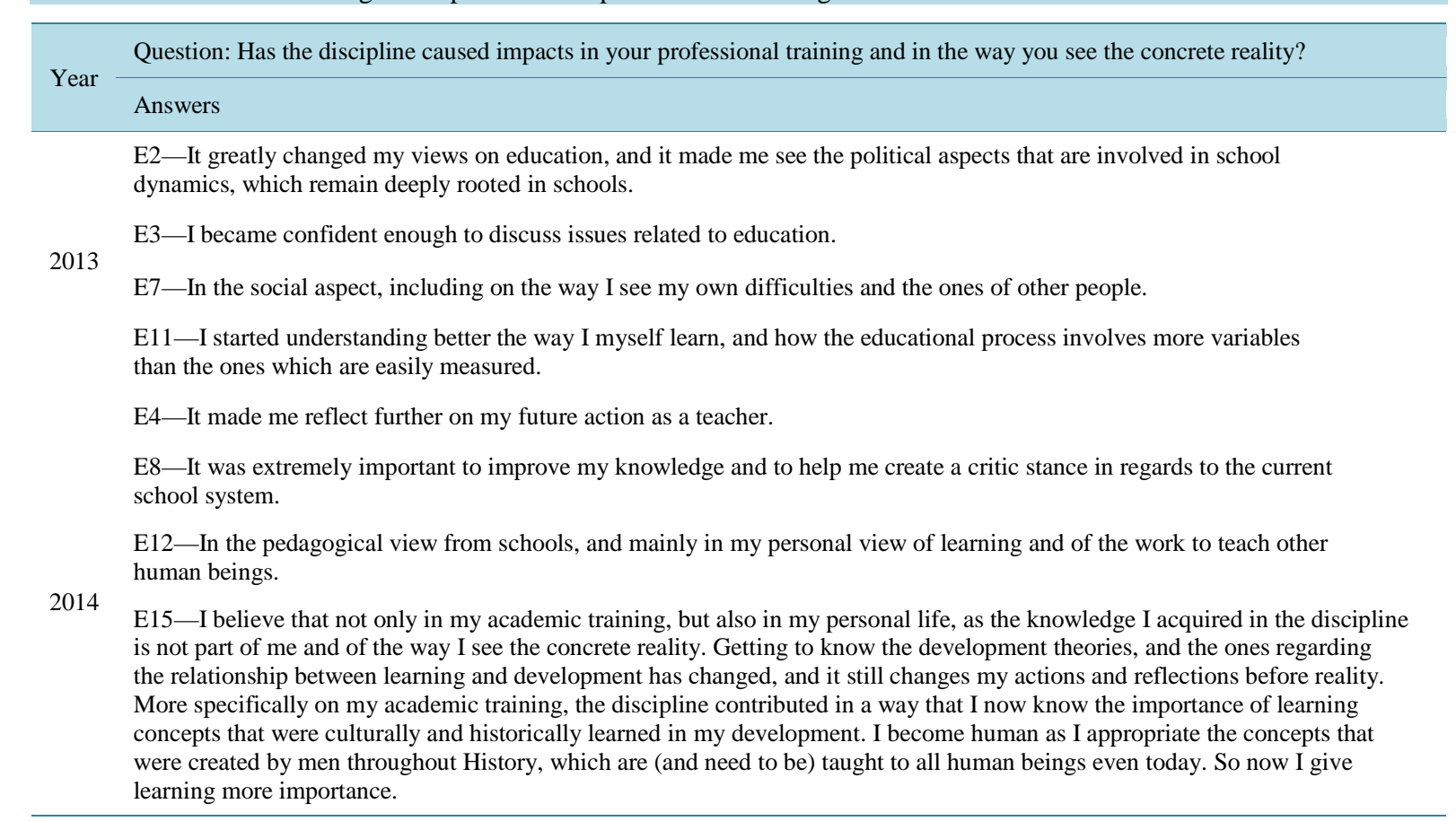


that are faced in the learning process, the action methods in the pedagogical activity are shown to create favorable conditions for the personal transformation of the subjects who were involved in the process.

\section{Final Considerations}

The previously-presented analysis of data allows us to conclude that the pedagogical activity that is conducted promoted transformations in the way students think and act, in regards to the studied contents and to their professional training. However, the need to highlight some aspects in regards to the action methods in the pedagogical activity is made clear.

The active intervention from teachers in the pedagogical activity is shown to be relevant to the training of future teachers, as the initial reasons in the activity from the study activities need to be transformed through the teacher's action in a way to put them in a study activity, once that does not take place spontaneously in the professional training at the undergraduate level. Another aspect to consider is the importance of the active participation of all subjects in the pedagogical activity. It is up to the teacher to take action, by explaining the theoretical concepts to be internalized by students, and students should take an active part in the process of study and reflection of studied contents. The collaborative participation of monitors in the pedagogical activity is considered to be relevant for students to conduct study actions which are objectified in their personal transformation, taking into account the possibility of individual intervention in the process to surpass the current development of each subject.

Such pedagogical activities, although considered relevant for educational organization in a specific context, i.e., in a society with a particular social organization, still need to be generalized or adapted to serve as a mean for the psychic development process of future professors. These are general formation activities for instructors, even though they might be specified in a research in a particular educational organization.

Research data indicate the need to extend the current study for the analysis of the unfolding of pedagogical activities shared with the students, and also require an evaluation of the influence of the professor's direct participation in the formation of future educators that will work with primary school students.

Thus, we reassert the need for a set of action methods in the pedagogical activity in the training of teachers, in a way to create conditions for a collaborative action among all those people who are a part of such activity, taking into account the goal of the collective activity — the development of higher psychological functions through the appropriation of scientific and theoretical concepts which promote the transformation of students' living personalities, and that transformation does not lie only in the way of teaching, but it remains throughout the whole lives of subjects.

\section{References}

Asbahr, F. da S. F., \& Lopes, J. S. (2006) “The Fault Is Yours” [“A Culpa é Sua”]. Psicologia USP, 17, 53-73.

Bernardes, M. E. M. (2009). Teaching and Learning as a Dialectic Unit in the Pedagogical Unity [Ensino e Aprendizagem Como Unidade Dialética na Atividade Pedagógica]. Psicologia Escolar e Educacional, 13, 235-242.

http://dx.doi.org/10.1590/S1413-85572009000200005

Bernardes, M. E. M. (2012). Symbolic Mediations in Pedagogical Activity: Contributions of Historic-Cultural Theory for Teaching and Learning [Mediações Simbólicas na Atividade Pedagógica: Contribuições da Teoria Histórico-Cultural para o Ensino e a Aprendizagem]. Curitiba, PR: CRV.

Bernardes, M. E. M. (2014). Active Teaching Approach: Teaching and Learning Methods on Historical and Cultural Theory. Creative Education, 5, 734-742. http://dx.doi.org/10.4236/ce.2014.510086

Bernardes, M. E. M., \& Moura, M. O. de. (2009). Symbolic Mediations in the Pedagogical Activity [Mediações Simbólicas na Atividade Pedagógica]. Educação e Pesquisa, 35, 463-478. http://dx.doi.org/10.1590/S1517-97022009000300004

Davidov, V. V. (1988). La Enseñanza Escolar y el Desarrollo Psíquico: Investigación Psicológica Teórica y Experimental. Moscu: Progresso.

Facci, M. G. D. (2010). Vygotsky and the Teaching-learning Process: The Development of Concepts [Vygotsky e o Processo de Ensino-aprendizagem: A Formação de Conceitos]. In Vygotsky and the School Current: Theoretical Foundations and Implications Pedagogical [Vygotsky e a Escola Atual:Fundamentos Teóricos e Implicações Pedagógicas] (pp.123-148). Marília, SP: Cultura acadêmica.

Freitas, R. A. M. da M. (2012). School Culture as a Didactic Question [Cultura Escolar Como uma Questão Didática]. In J. C. Libâneo, \& N. Alves (Eds.), Temas de Pedagogia:Diálogos entre Didática e Curriculo (pp. 127-151). São Paulo: Cortez. 
Gil, A. C. (1999). Methods and Techniques of Social Research [Métodos e Técnicas de Pesquisa Social] (4th ed.). São Paulo: Pioneira.

Guzzo, R. S. L., et al. (2010). Psychology and Education in Brazil: A Historic Vision and Possibilities in this Relationship [Psicologia e Educação no Brasil: Uma Visão da História e Possibilidades Nessa Relação]. Psicologia: Teoria e Pesquisa [Online], 26, 131-141.

Kostiuk, G. S. (2005). Some Aspects of the Reciprocal Relationship between Education and Personality Development (Alguns Aspectos da Relação Recíproca Entre Educação e Desenvolvimento da Personalidade). In A. N. Leontiev, A. R. Luria, L. S. Vygotsky, \& G. S. Kostiuk (Eds.), Psicologia e Pedagogia: Bases Psicológicas da Aprendizagem e do Desenvolvimento (pp. 43-62). São Paulo: Centauro.

Leontiev, N. A. (1983). Activity, Conscience, Personality (Actividad, conciencia, personalidade). Cuba: Pueblo e Educacion.

Leontiev, N. A. (2005). The Principles of Mental Development and the Problem of Mental Retardation (Os Princípios do Desenvolvimento Mental e o Problema do Atraso Mental). In A. N. Leontiev, A. R. Luria, L. S. Vygotsky, \& G. S. Kostiuk (Eds.), Psicologia e Pedagogia: Bases Psicológicas da Aprendizagem e do Desenvolvimento (pp. 87-105). São Paulo: Centauro.

Libâneo, J. C. (2012). The Inside-Out of School Relationships or the Interfaces between Socio-Cultural Practices and Teaching (As Relações Dentro-fora na Escola ou as Interfaces Entre Práticas Socioculturais e Ensino). In J. C. Libâneo, \& N. Alves (Eds.), Temas de pedagogia: Diálogos entre didática e currículo (pp. 35-60). São Paulo: Cortez.

Luckesi, C. C. (2012). Assessment of Learning in Schools (Avaliação da Aprendizagem na Escola). In J. C. Libâneo, \& N. Alves (Eds.), Temas de Pedagogia: Diálogos Entre Didática e Currículo (pp. 433-451). São Paulo: Cortez.

Luria, A. R. (1987). Thought and Language: The Last Conferences of Luria (Pensamento e Linguagem: As Últimas Conferências de Luria). Porto Alegre, RS: Artes Médicas.

Luria, A. R. (2005). The Role of Language in the Formation of Temporal Conexions and the Regulation of Normal and Oligofrenic Children Behavior (O Papel da Linguagem na Formação de Conexões Temporais e a Regulação do Comportamento em Crianças Normais e Oligofrênicas). In A. N. Leontiev, A. R. Luria, L. S. Vygotsky, \& G. S. Kostiuk (Eds.), Psicologia e Pedagogia: Bases Psicológicas da Aprendizagem e do Desenvolvimento (pp. 107-123). São Paulo: Centauro.

Moura, M. O. de. et al. (2010). Teaching-Orienting Activities as Na Unity between Teaching and Learning (A Atividade Orientadora de Ensino como Unidade Entre Ensino e Aprendizagem). In M. I. B. Serrão, \& L. Meinert (Eds.), Atividade Pedagógica na Teoria Histórico Cultural (pp. 81-109). Brasília: Liber livro.

Oliveira, B. A. de. (2010). Marxist Philosophical Fundaments of the Works of Vygotsky: The Question of Activity Category of Some Implications for the Educational Work (Fundamentos Filosóficos Marxistas da Obra Vygotskyana: A Questão da Categoria de Atividade de Algumas Implicações para o Trabalho Educativo). In S. G. de L. Mendonça, \& S. Miller, (Orgs.), Vygotsky e a Escola Atual: Fundamentos Teóricos e Implicações Pedagógicas (pp. 3-26). Marília, SP: Cultura acadêmica.

Patto, M. H. S. A. (1983). Production of School Failure: Stories of Submission and Rebellion (Produção do Fracasso Escolar: Histórias de Submissão e Rebeldia). São Paulo: T. A. Queiroz.

Piaget, J. (1983). Genetic Epistemology (A epistemologia genética). (Os Pensadores) Trad. Nathanael C. Caixeiro, São Paulo: Abril Cultural.

Richardson, R. J. (1999). Social Research: Methods and Techniques (Pesquisa Social: Métodos e técnicas) (3rd ed.). São Paulo: Atlas.

Saviani, D. (2003). Historic-Critic Pedagogy: First Approaches (Pedagogia Histórico-crítica: Primeiras Aproximações) (8th ed.). Rev. e ampl, Campinas: Autores Associados.

Tanamachi, E. de R., \& Meira, M. E. M. (2003). The Psychologist Work as Expression of Critical Thinking in Psychology and Education (A Atuação do Psicólogo como Expressão do Pensamento Crítico em Psicologia e Educação). In M. A. M. Antunes, \& M. E. M. Meira (org.), Psicologia Escolar: Práticas Críticas (pp. 11-62). São Paulo: Casa do Psicólogo.

Vygotsky, L. S. (1996). Selected Works (Obras Escogidas). Madrid: Machado Libros.

Vygotsky, L. S. (2007). The Social Formation of the Mind (A formação Social da Mente). São Paulo: Martins Fontes.

Vygotsky, L. S. (2010). Pedagogical Psychology (Psicologia Pedagógica). São Paulo: Martins Fontes. 